\title{
Experience, Board Size, and Firm Capital Structure
}

\author{
Muhammad Ronald Yusuf \\ Faculty of Economics and Business \\ Universitas Indonesia \\ Depok, Indonesia \\ muhronaldyusuf@gmail.com
}

\author{
Liyu Adhi Kasari Sulung \\ Faculty of Economics and Business \\ Universitas Indonesia \\ Depok, Indonesia \\ liyu.adhi@ui.ac.id
}

\begin{abstract}
This empirical research aims to identify the effect of chief executive officer (CEO) experience and board size on a firm's capital structure in three-top industries mining, agriculture, and consumer goods - companies within year 2010-2016. This paper uses tradeoff theory to investigate top managers' managerial experience and board size as elements of capital structure. The research result found that the experience from top manager positively influences to capital structure's book value, therefore the increasing of managers' experience years will be aligned with total and long term- debt of the company. Meanwhile, another independent variable, board size, negatively gives influence on the capital structure. Finally, our results are proved to be robust in both dependent variables, total market value and long-term debt proxies.
\end{abstract}

Keywords-capital structure, corporate governance, executive experience, theory of trade-off

\section{INTRODUCTION}

Debt is a tool that companies can use to improve its capital structure to increase its performance (Detthamrong et al., 2017). In 2015, when the economy was sluggish, many companies - particularly non-financial companies - added to their debt to improve their performance and value. For example, mining sector companies that usually have more capital than debt because of high retained earnings experienced capital deficiencies from declining mining commodity prices and demand for mining materials from China (Rembeth, 2015). Therefore, the higher debt level negatively affected the company's financial performance because it reduced profits and affected the capital on the company's balance sheet. To overcome the decline in company performance, many non-financial and banking companies innovate by increasing their debt to improve performance through the purchase of new fixed assets or by expanding their business. However, without good governance, adding debt increases the probability of a crisis if not properly regulated. Therefore, there are two financial crisis which is initiated by the corporate funding decisions; Asian and global crises in 1997 and 2007, respectively (Detthamrong et al., 2017).

According to research by Jensen (1986), corporate funding decisions have a close relationship with decision making by the top level manager. This relationship can be observed through corporate governance relations of top level managers with company performance (Anderson et al., 2004). Zhang et al. (2015) also examined leadership behavior that differed from those of chief executive officers (CEOs) of each subsidiary in China and observed their effect on team or group effectiveness and company performance. In addition Srivastava (2013) found that CEOs have extraordinary abilities that are important to organizational performance and measured the ability of top executive members to forecast risk using information about how they trade their personal equity by utilizing their experience. Finally, Matemilola et al. (2018) found that CEO experience has a significant positive influence on the company's capital structure by arguingusing upper echelon theory by Hamburger and Mason (1984) - that strategic decisions such as financing choice are influenced by the CEO's individual characteristics and that a larger capital structure results in a higher company value from the higher tax shield generated by the interest on debt.

In relation to the number of principal executives, the board of directors is an important element in corporate governance to regulate the company's operational effectiveness and suitability. According to Chancharat et al. (2012), this element has a essential role to mitigate corporate failure. According to Jensen (1986), companies with more directors have more leverage to reduce agency costs. Having positive relationship between two elements, number of top executives and leverage, seems to support the companies' behavior with more directors to take the advantage of their directors' network and external financing access. This research finding was also followed by the findings of Abor (2007) and Bokpin (2009), who noted that a positive relationship exists between the number of directors and leverage. These findings suggest that a larger number of board of principal executives increases the company's leverage and value.

On the other side, Berger et al. (1997) revealed that number of top executives number negatively affect financial leverage. This finding was followed by those of Wiwattanakantang (1999) and Anderson et al. (2004), who indicated a significant negative relationship between the number of directors and the company's capital structure. Previous research indicates that each additional member of the board of directors reduces the financing cost from debt. Yermack (1996) revealed that the more number of directors board, the less efficient management supervision, this will happened because more directors lead to more complex coordination and decision making among them and, therefore, will result higher debt ratio of the company and add to risky assets.

Researchers have made several crucial contributions to the capital structure literatures. First, this study attempts to combine the experience of the top executives as a director and the number of directors in a variable corporate governance structure that will affect the company's capital 
structure. Custódio and Metzger (2014), Papadakis and Barwise (2002) measured the experience years of a CEO in his or her position by calculating the date of a CEO was first appointed until the years that he or she worked outside the company. This is because most CEOs bring their gained experience from other companies to current position. Managing director experience is associated with their skills and ability (Escriba et al., 2009). Second, this study also uses framework of tradeoff theory from Myers (1984) to integrate insights from upper echelon and tradeoff theories to enlighten the correlation between principal executive experience and capital structure. Third, researchers used samples from 2010 to observe stability after the 2008 global financial crisis. Then, the three largest industries were taken as samples using the mean return from the index of the per sector from 2010 to 2016. Based on previous research, this research is aimed at determining how the competence and experience of directors and the number of directors influence the decision-making of a company's capital structure.

This capital structure study aims to examine the effect of managing director experience and the number of directors on the debt (capital structure) in three top industries including agricultural, mining, and consumer goods.

\section{LITERATURE REVIEW}

\section{A. Upper Echelon Theory}

Upper echelon theory identifies experience attributes as given indicators of what chief directors carry to the current companies (Hambrick and Mason, 1984). In particular, upper echelon theory discusses that top board experience from their previous works may affect their decision making. In addition, Finkelstein (1992) indicated that the attributes of the chief executive, including experience, is able to contribute the stronger predictions of strategic outcomes. The CEO's experience is associated by using their cognitive abilities to shape their strategic decisions. The fundamental assumption shaping this theory is that the experience years can be recognized as a substitute for the chief director's cognitive abilities. Moreover, this theory also identifies chief directors as the significant human resources who apply their gained experience to construct effective strategies, for instance capital financing decisions. Likewise, experienced directors is predicted can produce high-quality decisions as they possess the cognitive ability to address complex issues and affect strategic and effective results (Hambrick \& Mason, 1984).

In particular, upper echelon theory explains that the features such as top management experience might affect strategic choices. Upper echelon theory (see Figure 1) suggests that the company's chief executive is an important source of his or her success because of the significant influence that the president has on strategic decisions and strategic outcomes (Barney, 1991). In addition, Finkelstein (1992) suggested that the chief directors' experience is able to predict result in stronger strategic predictions.

\section{B. Relationship Between Corporate Governance and Firm Capital Structure}

Corporate governance can be explained as a framework for developing an environment of accountability, reliance, and also transparency. Corporate governance in profitable corporation is able to solve the agency problems because of the separating several agents such as managers and shareholders. Corporate governance can be used to reduce the conflict between agents that may affect the corporation's capital structure. Moreover, Chang et al. (2014) argued that there are two variables, including company's unique features and conflicts of interest between managers and shareholders, that can substantially affect the liability of the profitable company. A strong level of corporate governance owned by a company can alleviate the agency costs. This is because main managers tend to seek for lower level of corporate financial leverage when solving good corporate governance from the top executive members (Wen et al., 2002). Therefore, corporate governance delivers procedures to overcome the problems among interested parties in order to maximize company value by managing the fund.

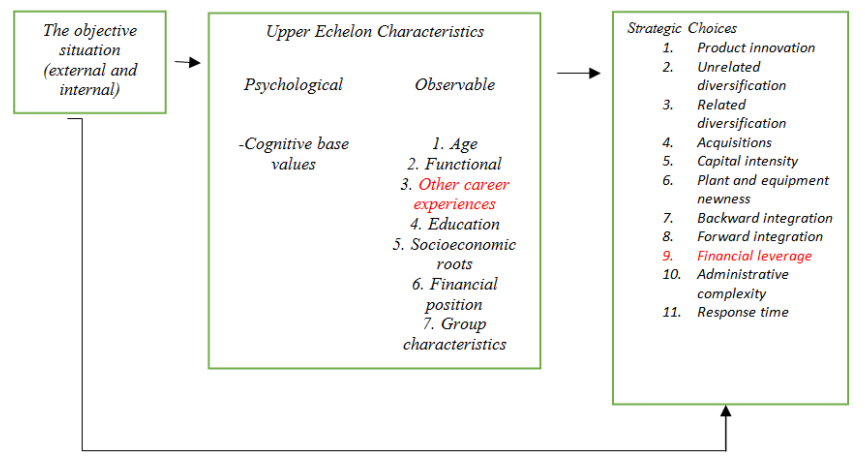

Fig. 1. Upper Echelon Perspective of an Organization (Hambrick \& Mason, 1984).

\section{Optimal Capital Structure}

Research on capital structure explains the indifferent choice between debt and capital which can not affect the company's value by having the assumption of perfect markets (Modigliani and Miller, 1958). However, the capital structure selection decision becomes problematic because of the tax, information differences, and agency costs. Moreover, capital structure theory had developed and Myers (1984) tried to research that the optimal level of capital structure can be gained through the benefits of the tax shield from balanced debt, margins, and the cost of financial pressure. In addition, debt is replaced with equity and vice versa until the value of the company is maximized. Researchers argued that, assuming all other factors remain constant, experienced directors use more debt to protect profits of corporation from taxes, which this movement is able to encourage the use of more debt rather than equity. This research draws on insights from upper echelon theory, integrates them with exchange capital structure theory, and focuses on tradeoff theory because it implies that the chief director maximizes the benefits of the tax shields from interest on debt.

\section{Hypothesis Development}

Based on the background, problem formulation, purpose of the study, and review and presentation of prior studies, the research hypothesis is developed as follows.

\section{1) Experience}

The experience of the CEO is the main independent variable of researchers and research using the chief director's total experience. Custódio and Metzger (2014) reflect the top executives' experience with using dummy variables in the field of financial research. Using the number of directors for 
the year spent in the same position, president director's experience has an important effect on their planned decisions (Papadakis and Barwise, 2002). Moreover, there is a significant research result found by Matemilola et al. in year 2018 who found a substantial relationship between the president director's experience and leverage, which explains that good strategic decisions - in this case is leverage-are influenced by the characteristics of the president director. One such characteristic is work experience, and the president director with significant experience tends to increase leverage, which increases company value and protects profits from taxes. Holding constant the assumption of company assets and constant investment plans, the experienced director directs the optimal mix of capital structures that maximizes the benefits of the tax shield from interest on debt and is more inclined toward debt. Therefore, the research hypothesis is as follows.

\section{H1: Experience has a significant positive influence on the company's capital structure.}

\section{2) Board size}

The board of directors is the structural elements of corporate governance to oversee how the main operations goes well in the company. This element plays an important role in reducing corporate failures and represents the responsibility to monitor key activities and approve strategic decisions (Chancharat et al., 2012). In Yermack (1996) research result, he argued that larger boards may influence to lessen the efficiency of monitoring management. This activities such as coordination, communication, and decision making can make a burdensome for large boards and thus make their role become less effective.

Jensen (1986) in his previous research also found that firms with larger number of board sizes had higher level of leverage than firms with smaller board sizes through using more debt than equity financing. This result has an indication that more top executive numbers has the ability to give them better access of external financing. Therefore, this study proposes the following hypothesis.

\section{H2: Board size has a significant positive influence on the company's capital structure.}

\section{RESEARCH METHOD}

\section{A. Data and Data Collection Method}

Researchers use financial statements and annual reports from companies in the mining, agriculture, and consumer goods industries that are available from the Indonesia Stock Exchange (BEI) during 2010-2016. Researchers used samples from 2010 to observe stability after the global financial crisis of 2008 and the highest sector from the mean return of the persector index during 2010-2016.

\section{B. Data Collection Method}

We tries to use the panel method used to collect data in purposive sampling, which takes data from 64 mining, agriculture, and consumer goods companies with a listing date in year 2010 and above.
TABLE I. SUMMARY OF RESEARCH VARIABLES

\begin{tabular}{|c|c|c|}
\hline Variable & Measurement & Source \\
\hline \multicolumn{3}{|c|}{ Dependent } \\
\hline $\begin{array}{l}\text { TDBV }(\text { book } \\
\text { value of total } \\
\text { debt })\end{array}$ & $\begin{array}{l}\text { Long-term debt ratio plus long- } \\
\text { term debt per total assets }\end{array}$ & $\begin{array}{l}\text { Firm's annual } \\
\text { reports and Bursa } \\
\text { Efek Indonesia } \\
\text { (B.T. Matemilola, } \\
\text { 2017) }\end{array}$ \\
\hline $\begin{array}{l}\text { LDBV (book } \\
\text { value of long- } \\
\text { term debt) }\end{array}$ & $\begin{array}{l}\text { Ratio of total debt per book value } \\
\text { of total assets }\end{array}$ & $\begin{array}{l}\text { Firm's annual } \\
\text { reports and Bursa } \\
\text { Efek Indonesia } \\
\text { (B.T. Matemilola, } \\
\text { 2017) }\end{array}$ \\
\hline $\begin{array}{l}\text { TMDV } \\
\text { (market value } \\
\text { of the } \\
\text { corporation's } \\
\text { total debt) }\end{array}$ & $\begin{array}{l}\text { Ratio of firm's total debt divided } \\
\text { by market value of firm's equity } \\
\text { plus book value of total debt }\end{array}$ & $\begin{array}{l}\text { Firm's annual } \\
\text { report and Bursa } \\
\text { Efek Indonesia } \\
\text { (B.T. Matemilola, } \\
\text { 2017) }\end{array}$ \\
\hline $\begin{array}{l}\text { LDMV } \\
\text { (market value } \\
\text { of the } \\
\text { corporation's } \\
\text { long-term } \\
\text { debt) }\end{array}$ & $\begin{array}{l}\text { Ratio of firm's long-term debt } \\
\text { divided by market value of equity } \\
\text { plus book value of long-term debt }\end{array}$ & $\begin{array}{l}\text { Firm's annual } \\
\text { report and Bursa } \\
\text { Efek Indonesia } \\
\text { (B.T. Matemilola, } \\
\text { 2017) }\end{array}$ \\
\hline \multicolumn{3}{|c|}{ Independent } \\
\hline $\begin{array}{l}\text { Pengalaman }_{i, t} \\
\text { (CEO's career } \\
\text { experience) }\end{array}$ & $\begin{array}{l}\text { Total number of experience years } \\
\text { experience of the CEO. the date } \\
\text { from the CEO was first appointed } \\
\text { in the board until until the years } \\
\text { worked outside the company. }\end{array}$ & $\begin{array}{l}\text { Firm's annual } \\
\text { report and Bursa } \\
\text { Efek Indonesia } \\
\text { (B.T. Matemilola, } \\
\text { 2017) }\end{array}$ \\
\hline $\begin{array}{l}\text { Board size } \\
\text { (number of } \\
\text { directors) }\end{array}$ & $\begin{array}{l}\text { Number of boards of directors at } \\
\text { the company }\end{array}$ & $\begin{array}{l}\text { Firm's annual } \\
\text { report and Bursa } \\
\text { Efek Indonesia } \\
\text { (Paulo Alves, } \\
\text { 2015) } \\
\end{array}$ \\
\hline \multicolumn{3}{|c|}{ Control } \\
\hline 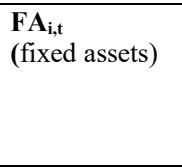 & $\begin{array}{l}\text { Ratio of fixed asset to book value } \\
\text { of total assets }\end{array}$ & $\begin{array}{l}\text { Firm's annual } \\
\text { report and Bursa } \\
\text { Efek Indonesia } \\
\text { (B.T. Matemilola, } \\
\text { 2017) }\end{array}$ \\
\hline $\begin{array}{l}\mathbf{P R F}_{\mathrm{i}, \mathbf{t}} \\
\text { (profit) }\end{array}$ & $\begin{array}{l}\text { Profit before taxes, interest, and } \\
\text { depreciation divided by the total } \\
\text { book value of assets }\end{array}$ & $\begin{array}{l}\text { Firm's annual } \\
\text { report and Bursa } \\
\text { Efek Indonesia } \\
\text { (B.T. Matemilola, } \\
\text { 2017) }\end{array}$ \\
\hline $\begin{array}{l}\text { Size }_{i, t} \\
\text { (firm size) }\end{array}$ & Logarithm of total sales & $\begin{array}{l}\text { Firm's annual } \\
\text { report and Bursa } \\
\text { Efek Indonesia } \\
\text { (B.T. Matemilola, } \\
\text { 2017) }\end{array}$ \\
\hline $\begin{array}{l}\mathbf{P B}_{\mathrm{i}, \mathrm{t}} \\
\text { (price to book } \\
\text { ratio) }\end{array}$ & $\begin{array}{l}\text { Ratio of company's debt book } \\
\text { value plus market value of capital } \\
\text { per book value of total assets }\end{array}$ & $\begin{array}{l}\text { Firm's annual } \\
\text { report and Bursa } \\
\text { Efek Indonesia } \\
\text { (B.T. Matemilola, } \\
\text { 2017) }\end{array}$ \\
\hline $\begin{array}{l}\text { Ndts }_{\mathbf{i}, \mathbf{t}} \\
\text { (non-debt tax } \\
\text { shield) }\end{array}$ & Depreciation ratio per total assets & $\begin{array}{l}\text { Firm's annual } \\
\text { report and Bursa } \\
\text { Efek Indonesia } \\
\text { (B.T. Matemilola, } \\
\text { 2017) }\end{array}$ \\
\hline
\end{tabular}

\section{Variable Operationalization}

This research model represents a combination of research by Matemilola et al. (2018) and Alves et al. (2015) to determine the influence of a director's experience and corporate governance in terms of number of directors on the company's capital structure. The following models are used in this study (see Figure 2). 


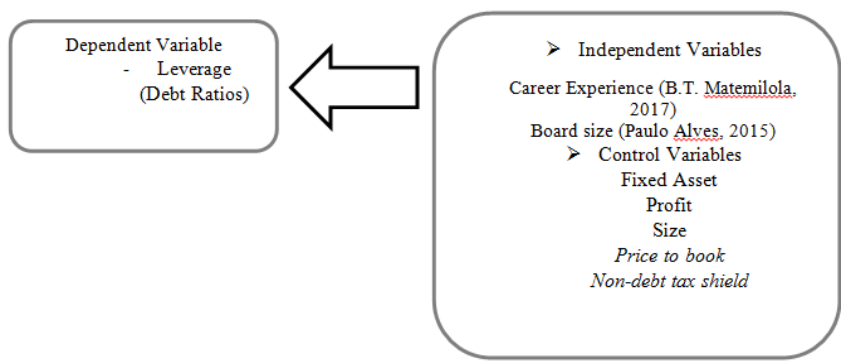

Fig. 2. Research Model

Debti,t $=\beta 0+\beta 1$ Pengalamani,t $+\beta 2$ Boardsize $\mathrm{i}, \mathrm{t}+$ $\beta 3$ FAi, $t+\beta 4$ PRFi, $t+\beta 5$ Sizei, $t+\beta 6 \mathrm{PBi}, \mathrm{t}+\beta \mathrm{Ndtsi}, \mathrm{t}+\varepsilon \mathrm{i}, \mathrm{t}$

Description

- Debti,t represents the debt ratio at firm i at time t;

- $\quad \beta 0$ represents a constant;

- Pengalamani,t represents the work experience of the president director of company $i$ at time $t$;

- Boardsize i,t represents the number of directors on the board of company $i$ at time $t$;

- $\quad F A i, t$ represents the fixed assets of firm $i$ at time $t$;

- $\quad$ PRFi,t represents the profit of firm $i$ at time $t$;

- Sizei,t represents the size of firm $i$ at time $t$;

- $\mathrm{PBi}, \mathrm{t}$ represents the price to book ratio of firm $\mathrm{i}$ at time t;

- Ndtsi,t represents the non-debt tax shield of firm i at time $\mathrm{t}$; and,

- $\quad \varepsilon i, t$ represents the residual.

\section{Analysis Techniques}

Following Nachrowi (2006), we apply a regression analysis from panel data method to capture the uniqueness of each cross section companies. This panel data processing method is divided into two panels: balanced and unbalanced panels. Based on the previous explanation, this research uses balanced panels.

The researcher then uses a fixed effect model, which assumes that different intercepts accommodate individual differences.

\section{ANALYSIS AND DISCUSSION}

This study uses a sample of three-top industries in Indonesia including mining, agriculture, and consumer goods companies from year 2010 to 2016. Researchers use secondary data derived from the official financial statements and annual reports of each company and the exchange website effects of Indonesia. From 2010 to 2016, 108 companies in the mining, agriculture, and consumer goods sectors were listed on the Indonesia Stock Exchange, of which 64 conducted public bidding before 2010 and reported on the work experience of the president director.

\section{A. Descriptive Analytics}

Table II indicates that the average mining, agriculture, and consumer goods companies in Indonesia are viewed as good because the average debt ratio is still lower than 1, indicating that these companies are still relatively healthy financially and do not experience financial problems when the debt ratio is reasonable. PT Bumi Resources has the highest ratio of debt to book value of assets (TDBV), at 1.8977, and has a ratio of LDBV in about 1.6513. These ratios are the result of a significant capital deficiency of US\$2.785 million in 2016, which was caused by the high debt and interest burden and declining coal sales from a reduction in commodity prices, creating a severe deficiency in Bumi's capital. PT Adaro's largest ratio of TDMV and LDMV amounted to 0.9995 and 0.9994, respectively, in 2015. These ratios were the result of the significant decline in net income and sales. A decrease in 2015 net income by $17 \%$ relative to the previous year was caused by instability in the world economy. The lowest debt ratio was that of PT Inti Agro Resources, which has a TDBV of 0.0036 and a LDBV of 0.0017 . These low ratios were caused by PT IIKP issuing more shares than bonds in 2010. The lowest TDMV is of PT Multi Bintang Indonesia, at 0.000314 in 2012, and the lowest LDMV was 0.001171 , resulting from the capitalization value of PT Multi Bintang in 2012 and 2013 being very large relative to its debt. This situation resulted in PT Multi Bintang issuing more shares than bonds.

The independent variable of experience represents the amount of time that the president director worked, in units of years, before and during his or her work at the company at which the chief director serves. The company with a president director with the most experience is Tunas Baru Lampung, led by Mr. Widarto, who has 50 years of work experience. Mr. Widarto started his career in 1966 in the Budi river business group. Inti Agro Resources has a president director with the least experience-Susanti Hidayat, who started his career in 2001. The independent variable board size acts as a proxy for the number of directors at the company. Each industry has an average of five directors consisting of one president director and four individuals responsible for carrying out four management functions, namely, financial, marketing, operations, and human resources. PT Mandom Indonesia has the largest number of directors at 15. Inti Agro Resources has the fewest number of directors, at two.

TABLE II. DESCRIPTIVE ANALYTICS

\begin{tabular}{|l|l|l|l|l|l|}
\hline & Mean & Maximum & Minimum & $\begin{array}{c}\text { Std. } \\
\text { Dev. }\end{array}$ & Observation \\
\hline TDMV & 0.3910 & 0.9995 & 0.0003 & 0.2935 & 448 \\
\hline TDBV & 0.4533 & 1.8976 & 0.0035 & 0.2621 & 448 \\
\hline LDBV & 0.2047 & 1.6513 & 0.0017 & 0.2084 & 448 \\
\hline LDMV & 0.2651 & 0.9994 & 0.0001 & 0.2866 & 448 \\
\hline $\begin{array}{l}\text { EXPE } \\
\text { RIENC } \\
\text { E }\end{array}$ & 1 & & & & \\
\hline $\begin{array}{l}\text { BOAR } \\
\text { D } \\
\text { SIZE }\end{array}$ & 5.2522 & 15.000 & 2.000 & 2.0696 & 448 \\
\hline
\end{tabular}




\section{B. Classic Asumption Test}

Table III shows that no correlation higher than 0.8 exists, indicating that the regression model used in this study does not have a multicollinearity problem. The modified Wald test shows that the model has heteroskedasticity problems. The Wooldridge test indicates that the model has an autocorrelation problem. According to Gujarati (2009) in his book, Basic Econometrics, the generalized least square estimation method (GLS) can be used to overcome the violation of the classical assumption of autocorrelation and heteroskedasticity in a regression model.

\section{Analysis of Regression Test}

Table III shows the overall results of the four regression estimates that indicate the influence of the experience of the president director and the number of directors on the company's capital structure.

Experience variables represent the amount of experience that the president director working at the company has and the experience working with other companies before joining the current company. Based on Table III, the independent variables for experience have a positive and significant effect on the dependent variables TDBV, LDBV, TDMV, and LDMV at a significance of $10 \%, 5 \%, 1 \%$, and $1 \%$, respectively. These results indicate that each additional year of experience contributes 0.00263 for TDBV, 0.00229 for LDBV, 0.00513 for TDMV, and 0.00419 for LDBV, indicating that the experience independent variable has a significant positive effect on TDBV, LDBV, TDMV, and LDMV in accordance with the research hypothesis that experience has a positive influence on a company's capital structure.
These findings are consistent with Matemilola et al. (2018), who analyzed the connection between top executive's experience and funding decision of profitable companies. The results support the researchers' argument that top managers use more debt in their financing decisions to protect the corporate earnings from taxes also known as tax shield. The results support the first hypothesis that states that the president director's experience with debt is positive. The results also support the upper echelon theory which states that executive attributes such as experience may influence their strategic choices. The president director with long-term experience tends to have various connections to make a deal with debt financing, therefore this may maximizes the optimal mix of capital structure to gain benefits of tax shield and thus may increases company value.

Based on the results in Table III, board size of top executives negatively affect debt financing in strong level of significance. These findings are consistent with Yermack (1996), who found that the more number of directors results in less efficient management supervision because more directors result in more complex coordination and decision making and a larger number of directors further reduces the ratio of corporate debt or increases risky assets. These findings are also supported by Alves et al. (2015) and Heng et al. (2012) who found that a company with a higher number of directors reduces its debt ratio and adds risky assets to increase its performance. This is because larger boards of top managers may influence to lessen the efficiency of monitoring actitivities. This activities such as coordination, communication, and decision making can make a burdensome for larger boards of executives and thus make their role become less effective.

TABLE III. PARTIAL CORRELATION

\begin{tabular}{|c|c|c|c|c|c|c|c|c|c|c|c|}
\hline & TDMV & TDBV & LDBV & LDMV & FA & PRF & PB & NDTS & SIZE & EXP & Board \\
\hline TDMV & 1,000 & 0,411 & 0,438 & 0,914 & $-0,050$ & $-0,187$ & $-0,227$ & 0,018 & $-0,048$ & 0,148 & $-0,149$ \\
\hline TDBV & 0,411 & 1,000 & 0,695 & 0,378 & 0,132 & $-0,277$ & 0,068 & 0,142 & 0,142 & 0,103 & $-0,059$ \\
\hline LDBV & 0,438 & 0,695 & 1,000 & 0,564 & 0,101 & $-0,365$ & $-0,107$ & 0,109 & 0,039 & 0,121 & $-0,058$ \\
\hline LDMV & 0,914 & 0,378 & 0,564 & 1,000 & $-0,029$ & $-0,114$ & $-0,164$ & $-0,014$ & $-0,027$ & 0,115 & $-0,091$ \\
\hline FA & $-0,050$ & 0,132 & 0,101 & $-0,029$ & 1,000 & 0,080 & 0,130 & 0,341 & 0,143 & 0,102 & 0,019 \\
\hline PRF & $-0,187$ & $-0,277$ & $-0,365$ & $-0,114$ & 0,080 & 1,000 & 0,098 & $-0,037$ & 0,170 & 0,003 & 0,148 \\
\hline PB & $-0,227$ & 0,068 & $-0,107$ & $-0,164$ & 0,130 & 0,098 & 1,000 & 0,083 & 0,003 & $-0,130$ & $-0,049$ \\
\hline NDTS & 0,018 & 0,142 & 0,109 & $-0,014$ & 0,341 & $-0,037$ & 0,083 & 1,000 & $-0,051$ & 0,145 & $-0,126$ \\
\hline SIZE & $-0,048$ & 0,142 & 0,039 & $-0,027$ & 0,143 & 0,170 & 0,003 & $-0,051$ & 1,000 & 0,131 & 0,436 \\
\hline EXP & 0,148 & 0,103 & 0,121 & 0,115 & 0,102 & 0,003 & $-0,130$ & 0,145 & 0,131 & 1,000 & 0,147 \\
\hline Board & $-0,149$ & $-0,059$ & $-0,058$ & $-0,091$ & 0,019 & 0,148 & $-0,049$ & $-0,126$ & 0,436 & 0,147 & 1,000 \\
\hline
\end{tabular}


The SIZE variable in Table III as regression result table is significantly positive for TDBV and LDBV at strong level significance. This result is supported by tradeoff theory as triggered by Modigliani and Miller $(1958,1963)$ because a larger company will tend to be more stable in several conditions and less likely to face bankruptcy. These findings are clarified by the phenomenon that mining, agriculture, and consumer goods companies in Indonesia-especially mining - do not have large total assets in terms of book value; however, the market value of equity is very large in comparison. This market value is marked by a massive capitalization and its value is larger than the book value of the company's assets.

TABLE IV. REGRESSION RESUlTS

\begin{tabular}{|c|c|c|c|c|}
\hline & TDBV & LDBV & TDMV & LDMV \\
\hline Constant & $\begin{array}{l}0.0731 \\
(0.87)\end{array}$ & $\begin{array}{l}0.0214 \\
(0.26)\end{array}$ & $\begin{array}{l}0.355 * * * \\
(4.39)\end{array}$ & $\begin{array}{l}0.231 * * * \\
(2.80)\end{array}$ \\
\hline Experience & $\begin{array}{l}0.0031^{* *} \\
(2.30)\end{array}$ & $\begin{array}{l}0.0023^{* *} \\
(2.37)\end{array}$ & $\begin{array}{l}0.0051 * * * \\
(2.80)\end{array}$ & $\begin{array}{l}0.0042 * * * \\
(2.23)\end{array}$ \\
\hline Board size & $\begin{array}{l}-0.0148 * * \\
(-2.42) \\
\end{array}$ & $\begin{array}{l}-0.0068 \\
(-1.37) \\
\end{array}$ & $\begin{array}{l}-0.0258 * * * \\
(-3.42)\end{array}$ & $\begin{array}{l}-0.0178^{* *} \\
(-2.20)\end{array}$ \\
\hline SIZE & $\begin{array}{l}0.0435^{* * * *} \\
(4.62) \\
\end{array}$ & $\begin{array}{l}0.0102 * \\
(2.16)\end{array}$ & $\begin{array}{l}-0.0021 \\
(0.81)\end{array}$ & $\begin{array}{l}-0.0161 \\
(0.46)\end{array}$ \\
\hline FA & $\begin{array}{l}0.113^{*} \\
(1.57) \\
\end{array}$ & $\begin{array}{l}0.137 * * \\
(2.07)\end{array}$ & $\begin{array}{l}-0.0325 \\
(-0.51)\end{array}$ & $\begin{array}{l}0.0245 \\
(-0.03)\end{array}$ \\
\hline PRF & $\begin{array}{l}-0.171 * * * \\
(-5.89)\end{array}$ & $\begin{array}{l}0.163 * * * \\
(-7.48) \\
\end{array}$ & $\begin{array}{l}-0.0904 * * * \\
(-3.81)\end{array}$ & $\begin{array}{l}-0.0532 \\
(-2.17)\end{array}$ \\
\hline PB & $\begin{array}{l}0.0009 * * \\
(1.67)\end{array}$ & $\begin{array}{l}-0.0007 * \\
(-2.04)\end{array}$ & $\begin{array}{l}-0.0024 * * * \\
(-4.15)\end{array}$ & $\begin{array}{l}-0.0017 * * * \\
(-2.92)\end{array}$ \\
\hline ndts & $\begin{array}{l}0.0924 * \\
(0.68)\end{array}$ & $\begin{array}{l}0.0469 \\
(0.31) \\
\end{array}$ & $\begin{array}{l}-0.0049 \\
(0.71)\end{array}$ & $\begin{array}{l}-0.0468 \\
(-0.25)\end{array}$ \\
\hline Obs & 448 & 448 & 448 & 448 \\
\hline Rsquare & $16.0973 \%$ & $17.8768 \%$ & $11.9764 \%$ & $2.3649 \%$ \\
\hline Chi2 (Prob) & 0.000 & 0.000 & 0.000 & 0.000 \\
\hline
\end{tabular}

The fixed asset (FA) positively gives an impact to debt financing in several level of significance. These findings are also consistent with Hanousek and Shamsur (2011), and Matemilola et al. (2018) to support tradeoff theory which explains that long-term asset can be used as a guarantee to propose the debt financing choices. However, EBITDA has a significantly negative relationship debt financing choices in several level of significance and support pecking order theory. This theory deeply explore that the company prefer to use its internal sources or profits rather than corporate because of asymmetric information costs. Then, a more profitable company will reduce the proportion of its debt. However, the ratio of EBITDA per total asset to LDMV has no significant effect because it is higher than the $10 \%$ significance level. Although not significant, the relationship between PRF and LDMV remained negative, which still supports pecking order theory.

The control variable $\mathrm{PB}$ has a positive significant result to influence debt financing in both dependent variables. This result is consistent with the pecking order theory that companies requiring funds, such as agricultural, mining, and consumer goods, need to issue securities with little asymmetric information costs. These findings are similar to

Guney et al. (2011), and B.T. Matemilola et al. (2018). This result is in line with tradeoff theory, which states that developing firms need to use minimal debt to develop their business because there is the opportunity of bankruptcy is bigger than well-established firms (Myers, 1984).

NDTS positively gives impact on debt financing choices. This result aligns with Oino and Ukaegbu (2015) result which explains the positive relationship will be happened if there is a shield between debt and non-debt tax. Therefore, a higher non-debt tax shield results in a higher company debt ratio. However, the NDTS control variable on LDBV, TDMV, and LDMV has no significant effect. This finding can be explained using the phenomenon of agricultural, mining, and consumer goods companies preferring to issue bonds rather than increasing depreciation to protect from taxes and increase its value.

\section{CONCLUSION}

This study has a remarkable findings to support two hypothesis (experience and board size) to influence debt financing choices in three-top industries. The results of this paper reveal that top executive' experience is positively affect to debt financing choices. As a top manager's (CEO) experience increases, both two independent variables from the book value of total debt and the long-term debt ratios will also rise. It can be analyzed that the experienced director directs the optimal mix of capital structures that maximizes the benefits of the tax shield from interest on debt and is more inclined toward debt. The president director with longterm experience tends to have various connections to make a deal with debt financing, therefore this may maximizes the optimal mix of capital structure to gain benefits of tax shield.

Meanwhile, board size is negatively affect to book value measures of capital structure. Larger boards of top managers may influence to lessen the efficiency of monitoring activities because it has more complex coordination and decision making and thus a larger number of directors further reduces the ratio of corporate debt or increases risky asset. Our results are significantly robust through using both the total value of market debt and long-term debt ratios as the dependent variables.

\section{ACKNOWLEDGMENT}

We acknowledge this research was funded by the Directorate of Research and Community Engagement, Universitas Indonesia.

\section{REFERENCES}

[1] Alves, P., Couto, E. B., \& Francisco, P. M. (2015). Board of directors' composition and capital structure. Research in International Business and Finance, 35, 1-32. https://doi.org/10.1016/j.ribaf.2015. 03.005

[2] Abor, J. (2007). Corporate governance and financing decisions of Ghanaian listed firms. Corporate Governance, 7(1), 83-92. https://doi.org/10.1108/14720700710727131

[3] Anderson, R. C., Mansi, S. A., \& Reeb, D. M. (2004). Board characteristics, accounting report integrity, and the cost of debt. Journal of Accounting and Economics, 37(3), 315-342. https://doi.org/10.1016/j.jacceco.2004.01.004

[4] Berger, P. G., Eli, O., \& Yermack, D. L. (1997). Management Entrenchment and Capital Structure Decisions. The Journal of Finance, 52(4), 1411-1438.

[5] Bokpin, G. A., \& Arko, A. C. (2009). Ownership structure, corporate governance and capital structure decisions of firms: Empirical evidence from Ghana. Studies in Economics and Finance, 26(4), 246256. https://doi.org/10.1108/10867370910995708 
[6] Booth, L., Aivazian, V., \& Demirguc-kunt, A. (2001). American Finance Association Capital Structures in Developing Countries. The Journal of Finance, 56(1), 87-130.

[7] Bursa Efek Indonesia. Retrieved June 24, 2018, from Indonesia stock exchange; http://www.idx.co.id/data-pasar/data-saham/indeks-saham/

[8] Chakraborty, I., (2010). Capital structure in an emerging stock market: The case of India. Research in International Business and Finance 24, 295-314.

[9] Chancharat, N., Krishnamurti, C., \& Tian, G. (2012). Board structure and survival of new economy IPO firms. Corporate Governance: An International Review, 20(2), 144-163. https://doi.org/10.1111/j.14678683.2011.00906.x

[10] Chang, Y. K., Chou, R. K., \& Huang, T. H. (2014). Corporate governance and the dynamics of capital structure: New evidence. Journal of Banking and Finance, 48, 374-385. https://doi.org/ 10.1016/j.jbankfin.2014.04.026

[11] Custódio, C., \& Metzger, D. (2014). Financial expert CEOs: CEO's work experience and firm's financial policies. Journal of Financial Economics, 114(1), 125-154. https://doi.org/10.1016/j.jfineco.2014.06.002

[12] Detthamrong, U., Chancharat, N., \& Vithessonthi, C. (2017). Corporate governance, capital structure and firm performance: Evidence from Thailand. Research in International Business and Finance, 42(June), 689-709. https://doi.org/10.1016/j.ribaf.2017.07.011

[13] Escriba, A., \& Sanchez-Peinado, E. (2009). The influence of top management teams in the strategic orientation and performance of small and medium-sized enterprises, 20, 581-597. https://doi.org/ 10.1111/j.1467-8551.2008.00606.x

[14] Finkelstein, S. (1992). Power in top management teams : Dimensions, measurement. Academy of Management Journal, 35(3), 505-538. https://doi.org/10.2307/256485

[15] Flannery, M. J., \& Hankins, K. W. (2013). Estimating dynamic pane models in corporate finance. Journal of Corporate Finance, 19(1), 119. https://doi.org/10.1016/j.jcorpfin.2012.09.004

[16] Frank, M. Z., \& Goyal, V. K. (2009). Capital structure decisions: Which factors are reliably important? Financial Management, 38(1) 1-37. https://doi.org/10.1111/j.1755-053X.2009.01026.X

[17] Gormley, T.A., Matsa, D.A., (2013). Common errors: How to (and not to) control for unobserved heterogeneity. The Review of Financial Studies, 27(2), 617-661.

[18] Gujarati, D. (2009). Basic Econometrics. New York: Mc Graw Hill Book Co.

[19] Guney, Y., Li, L., Fairchild, R., (2011). The relationship between product markets competition and capital structure in Chinese listed firms. International Review of Financial Analysis, 20, 41-51.

[20] Hambrick, D. C., \& Mason, P. A. (1984). Upper echelons: The organization as a reflection of its top managers. Management, 9(2), 193-206. https://doi.org/10.2307/258434

[21] Hanousek, J., \& Shamshur, A. (2011). A stubborn persistence: Is the stability of leverage ratios determined by the stability of the economy? Journal of Corporate Finance, 17(5), 1360-1376. https://doi.org/10.1016/j.jcorpfin.2011.07.004

[22] Heng, T. B., Azrbaijani, S., \& San, O. T. (2012). Board of directors and capital structure: Evidence from leading malaysian companies. Asian Social Science, 8(3), 123-136. https://doi.org/10.5539/ ass.v8n3p123

[23] Jensen, M. (1986). American Economic Association Agency Costs of Free Cash Flow, Corporate Finance, and Takeovers Author (s): Michael C.ensen Source: The American Economic Review, Vol . 76, No . 2, Papers and Proceedings of the Ninety-Eighth Annual Meeting of the. American Economic Review, 76(2), 323-329.

[24] Jensen, M. C. (1993). The modern industrial revolution, exit, and the failure of internal control systems the Failure of internal control systems. Journal of Finance, 48(3), 831-880. https://doi.org/ 10.1111/j.1540-6261.1993.tb04022.x

[25] Jensen, M. C., \& Murphy, K. J. (2016). Performance Pay and TopManagement Incentives Author (s): Michael C.ensen and Kevin J.urphy Published by: The University of Chicago Press Stable URL : http://www.jstor.org/stable/2937665 REFERENCES references are available on JSTOR for thi, 98(2), 225-264
[26] Jiraporn, P., Kim, J. C., Kim, Y. S., \& Kitsabunnarat, P. (2012). Capital structure and corporate governance quality: Evidence from the Institutional Shareholder Services (ISS). International Review of Economics and Finance, 22(1), 208-221. https://doi.org/10.1016/ j.iref.2011.10.014

[27] Kyereboah-Coleman, A. (2007). Corporate governance and shareholder value maximization: An African perspective. African Development Review, 19(2), 350-367. https://doi.org/10.1111/j.14678268.2007.00165.x

[28] Lemmon, M., Roberts, M., \& Zender, J. (2008). Back to the beginning: persistence and the cross section of corporate capital structure. The Journal of Finance, 63(4), 1575-1608. https://doi.org/10.1111/j.1540-6261.2008.01369.x

[29] Matemilola, B. T., Bany-Ariffin, A. N., Azman-Saini, W. N. W., \& Nassir, A. M. (2018). Does top managers' experience affect firms' capital structure? Research in International Business and Finance, 45(January 2016), 488-498. https://doi.org/10.1016/j.ribaf.2017.07.184

[30] Matemilola., \& Bany Ariffin.N (2011). Pecking Order Theory of Capital Structure: Empirical Evidence from Dynamic Panel Data. International Journal Of GSTF Business Review, 1(1), 185-190.

[31] Modigliani, F., \& Miller, M. H. (1958). The American economic Revlew. The American Economic Review, 48(3), 261-297. Retrieved from http://www.jstor.org/stable/1809766

[32] Myers, S. C., \& Majluf, N. S. (1984). Corporate financing and investment decisions when firms have information that investors do not have. Journal of Financial Economics, 13(2), 187-221. https://doi.org/10.1016/0304-405X(84)90023-0

[33] Nachrowi, D. \& Usman (2006). Pendekatan Populer dan Praktis Ekonometrika:

[34] Nhung, L. T. P., \& Okuda, H. (2015). Effects of state ownership on companies' capital structure and profitability: Estimation analysis before and after the Lehman shock. Journal of Asian Economics, 38 , 64-78. https://doi.org/10.1016/j.asieco.2015.04.001

[35] Oino, I., \& Ukaegbu, B. (2015). The impact of profitability on capital structure and speed of adjustment: An empirical examination of selected firms in Nigerian Stock Exchange. Research in International Business and Finance, 35, 111-121. https://doi.org/10.1016/j.ribaf. 2015.03.004

[36] Papadakis, V. M., \& Barwise, P. (2002). How much do CEOs and top managers matter in strategic decision-making? British Journal of Management, 13(1), 83-95. https://doi.org/10.1111/1467-8551.00224

[37] Rajan, R. G., \& Zingales, L. (1995). What do we know about capital structure? Evidence from international data. The Journal of Finance. https://doi.org/10.2307/2329322

[38] Rembeth, Daniel (2015). Tahun 2015 Sebagai Tahun Terburuk Bagi Sektor Pertambangan: PricewaterhouseCoopers(PWC) press release. Retrieved June 07, 2018, from https://www.pwc.com/id/en/mediacenter/pwc-in-news/2016/indonesian/pwc---tahun-2015-sebagaitahun-terburuk-bagi-sektor-pertambangan.html

[39] Srivastava, A. (2013). Do CEOs possess any extraordinary ability? Can those abilities justify large CEO pay? Asia-Pacific Journal of Accounting and Economics, 20(4), 349-384. https://doi.org/10.1080/ 16081625.2013.828670

[40] Wen, Y., Rwegasira, K., \& Bilderbeek, J. (2002). Corporate governance and capital structure decisions of the Chinese listed firms. Corporate Governance: An International Review, 10(2), 75-83. https://doi.org/10.1111/1467-8683.00271

[41] Wiwattanakantang, Y. (1999). An empirical study on the determinants of the capital structure of Thai firms. Pacific-Basin Finance Journal, 7(3-4), 371-403. https://doi.org/10.1016/S0927$538 X(99) 00007-4$

[42] Yermack, D. (1996). Higher market valuation forfirms with a small board of directors. Journal of Financial Economics1, 40(1494), 185211.

[43] Zhang, X. A., Li, N., Ullrich, J., \& Van Dick, R. (2015). Getting everyone on board: The effect of differentiated transformational leadership by CEOs on top management team effectiveness and leader-rated firm performance. Journal of Management, 41(7), 18981933. https://doi.org/10.1177/0149206312471387 